\title{
Family Biopsychosocial Characteristics on Stunting Events in Children in Stunting Locus Areas Tapalang Barat District
}

\author{
Rahmat Haji Saeni $^{1}$, Erdiawati Arief ${ }^{2}$ \\ ${ }^{1,2}$ Department of Nutrition, Health Polytechnic, Ministry of Health, Mamuju, Indonesia \\ Corresponding Author: Rahmat Haji Saeni
}

DOI: https://doi.org/10.52403/ijhsr.20220118

\begin{abstract}
Background: Nutrition in the first five years of life is very important because at this time physical and brain development is most rapid. Nutrition at this time will affect future developments (Data, Information and Health, 2016). Anthropometric monitoring is also needed, as an initial screening of nutritional problems, including stunting and wasting, to facilitate interventions to be carried out to prevent long-term effects and the next stage in the toddler development cycle (Ramos, Dumith and César, 2015). The research method used in this study was case control, while the research was conducted from April to September 2020.

Purpose: This study aims to determine the relationship between biopsychosocial and stunting in children under five years in the stunting locus area, West Tapalang District.

Method: This study uses a case control research design with the number of respondents each as many as 57 people. The sampling method used is total sampling

Results: There is a statistical relationship between exclusive breastfeeding and the incidence of stunting. The $\mathrm{p}$ value is 0.01 with an OR value of 0.38 . Meanwhile, maternal height has a $\mathrm{p}$ value of 0.84 (OR 1.08), family support has a $\mathrm{p}$ value of 0.49 (OR 0.49), exposure to cigarette smoke has a $\mathrm{p}$ value of 0.09 (OR 0.31) and socioeconomic has no statistical relationship.

Conclusion: There is a relationship between exclusive breastfeeding and the incidence of stunting. Meanwhile, maternal height, family support, and exposure to cigarette smoke did not show a statistical relationship with the incidence of stunting
\end{abstract}

Keywords: Stunting, Toddler, psychosocial

\section{INTRODUCTION}

Currently, nutritional problems are still the center of attention in developing countries, including Indonesia. This can be seen in the formulation of the Sustainable Development Goals (SDGs), the second goal of which one of the outcomes in 2030 is to end all forms of malnutrition, including achieving the 2025 international target of reducing stunting and wasting in children under five (World Health Organization, 2016). This is in line with several Millennium Development Goals (MDGs) targets in Indonesia that have not been achieved (Lisbet, 2016). Every year, about 10.5 million child deaths are related to malnutrition, and it is reported that $98 \%$ of these deaths occur in developing countries (Dividend, 2007). The SDGs targets to be achieved by 2030, will ensure a sustainable food production system,

Growth and development have increased rapidly at the age of toddlers. This period is often referred to as the "Golden Age" phase. At the age of toddlers, the cognitive, physical, motoric, and psychosocial aspects of a child develop rapidly (Welasasih and Wirjatmadi, 2012). 
Factors that affect child development, in general, include: hereditary factors (genetic/congenital factors, gender, race/ethnicity, and age), as well as environmental factors which include the gestational (pregnancy) and postnatal period.

Nutrition in the first five years of life is very important because at this time physical and brain development is most rapid. Nutrition at this time will affect future developments (Data, Information and Health, 2016). Anthropometric monitoring is also needed, as an initial screening of nutritional problems, including stunting and wasting, to facilitate interventions to be carried out to prevent long-term effects and the next stage in the toddler development cycle (Ramos, Dumith and César, 2015).

\section{MATERIALS AND METHODS}

This research is analytical research using a case control research design. The respondents were all mothers who had stunting toddlers. while the controls are mothers who have toddlers with normal height. The inclusion criteria in this study were:

1. Willing to be involved in conducting research and

2. Have a Card Towards Health (KMS)??. Bisa menggunakanKMS Card

\section{Exclusion criteria:}

1. were not present at the time of the study.

2. Domiciled less than 1 year

\section{Statistical analysis}

This study uses an analytical descriptive statistic test using the Chi Square test. As for the analysis process using a computerized system.

\section{RESULTS}

Table 1. Characteristics of Respondents Based on Age, Education and Occupation in West Tapalang District in 2021

\begin{tabular}{|l|l|l|}
\hline Characteristics & Frequency & Percentage \\
\hline Age (Years) & & \\
\hline $20-29$ & 67 & 58.8 \\
$30-39$ & 34 & 29.8 \\
$>39$ & 13 & 11.4 \\
\hline Education & & \\
\hline Primary school & 73 & 64.0 \\
junior high school & 24 & 21.1 \\
high school & 17 & 14.9 \\
\hline Occupation & & \\
\hline Housewife & 114 & 100.0 \\
\hline
\end{tabular}

Based on table 1 above, it can be seen that the characteristics of most respondents based on the age group are 2029 years old, which is $58.8 \%$, while the lowest age group is the age group $>39$ years. which is $11.4 \%$. The most characteristic of respondents based on education level is elementary school education, which is $64.0 \%$, while the least education characteristic is high school education, which is $14.9 \%$. Characteristics based on the occupation of the respondents as a whole are housewives $(100 \%)$.

Table 2. Characteristics of Toddlers Based on Age, and Gender in West Tapalang District in 2021

\begin{tabular}{|l|l|l|}
\hline Characteristics & Frequency & Percentage \\
\hline Age & & \\
\hline 2 years & 44 & 38.6 \\
3 years & 46 & 40.3 \\
4 years & 24 & 21.1 \\
\hline Gender & & \\
\hline Man & 46 & 40.4 \\
Woman & 68 & 56.6 \\
\hline
\end{tabular}

Based on table 2 above, it can be seen that the most characteristics of toddlers based on age are 3 years, which is $40.3 \%$, while the minimum age of toddlers is 4 years, which is $21.1 \%$. Characteristics of toddlers who are male are $40.4 \%$ and girls are female by $56.6 \%$,

The relationship between the independent variable and the incidence of stunting

The following table describes the relationship between the independent variables (maternal height, breastfeeding, socioeconomic status and exposure to cigarette smoke). 
Rahmat Haji Saeni et.al. Family biopsychosocial characteristics on stunting events in children in stunting locus areas Tapalang Barat district.

Table 3. Relationship between Independent Variables and Stunting Incidence in West Tapalang District in 2021

\begin{tabular}{|l|l|l|l|l|}
\hline \multirow{2}{*}{ Variable } & \multicolumn{2}{|c|}{ Ooddler Nutritional Status } & \multirow{2}{*}{ P Value } & $\begin{array}{l}\text { OR } \\
\text { 95\% CI }\end{array}$ \\
\cline { 2 - 3 } & Stunting & No Stunting & & \\
\hline Maternal Height & & & & \\
\hline Short & $36(50.7 \%)$ & $35(49.3 \%)$ & \multirow{2}{*}{0.84} & 1.08 \\
Normal & $21(48.8 \%)$ & $22(51.2 \%)$ & & $0.50-2.29$ \\
\hline Breastfeeding & & & & \\
\hline Yes & $31(41.9 \%)$ & $43(58.1 \%)$ & \multirow{2}{*}{0.01} & 0.38 \\
No & $26(65.0 \%)$ & $14(35.0 \%)$ & & $0.17-0.86$ \\
\hline Family support & & & & \\
\hline No & $2(100 \%)$ & $0(0.0 \%)$ & \multirow{2}{*}{0.49} & 0.49 \\
Yes & $55(49.1 \%)$ & $57(50.9 \%)$ & & $0.40-0.59$ \\
\hline Exposure to Cigarette Smoke & & & & \\
\hline Yes & $46(46.5 \%)$ & $53(53.5 \%)$ & \multirow{2}{*}{0.09} & 0.31 \\
No & $11(73.3 \%)$ & $4(26.7 \%)$ & & $0.09-1.05$ \\
\hline
\end{tabular}

Based on table 3 above, it can be seen that the independent variable related to the incidence of stunting is breastfeeding for 6 months with a $\mathrm{p}$ value of 0.01 . while the variables of maternal height, family support and exposure to cigarette smoke did not show a statistical relationship. Meanwhile, the economic variables cannot be calculated because the income recognition of all respondents is below the provincial minimum wage.

\section{DISCUSSION}

\section{The relationship between maternal height and the incidence of stunting}

The condition of nutritional status and socioeconomic status was previously reflected in the maternal height. A person's height that is less can be caused by body conditions that are not fulfilled properly. The result is a lack of height which can also be the cause of less height in the next generation[1]. The mother's past nutritional condition can also be influenced by the mother's health status or illness.

Maternal height is part of gene expression that can be passed on to children. Thus, genetic factors are factors that cannot be changed, because genes are a direct gift from mother to child. Body mechanisms that are directly related to genetics give orders to cells that have been fertilized, so genetic factors are one of the factors that contribute to generational health problems [2].

The results showed that there was no statistical relationship between maternal height and the incidence of stunting. The $p$ value of this study is 0.84 while the OR value is 1.08 . In addition to genetic factors, maternal height can also be influenced by environment and nutrition[3]

Environment and nutrition play a very important role in stunting prevention efforts. Although the mother has a short height, but is supported by a good environment and good nutrition, stunting can be prevented. Therefore the first 1000 days of life become a very important variable to get attention[4].

Genes are carriers of traits that are passed down from parents to their children. The presence of inherited traits will affect hormone performance and affectgrowth. Growth hormone affects cortical bone deposition and may stimulate growth and height gain. To anticipate this, an adequate nutritional intervention must be carried out[5].

\section{The relationship between maternal breastfeeding and the incidence of stunting}

Exclusive breastfeeding for infants can be influenced by the mother's activities. One of them is occupational status or type of work. Mothers who have jobs have the potential not to exclusively breastfeed. Vice versa, mothers who work as housewives have a great opportunity to give exclusive breastfeeding[6]. Breast milk is food in the form of milk produced by the mother and contains the nutrients needed by the baby for the needs and development of the baby. [7].

Exclusive breastfeeding is very beneficial for babies in all respects, especially in providing complete nutrition, 
increasing body resistance or the immune system, increasing mental, emotional, and spiritual intelligence. In addition to the mother, breast milk is also beneficial for the readiness of the baby's organs in terms of ease of digestion and absorption. The nutrients contained in it are also complete including carbohydrates, calories, protein, and vitamins, protection against infectious diseases, protection against allergies. Breast milk also plays a role in increasing intelligence optimally[8]

The results showed that there was a statistical relationship between exclusive breastfeeding and the incidence of stunting with a $p$ value of 0.01 while the OR value of 0.38 . The chance of stunting in children can be reduced by breastfeeding; this is due to the micro and macronutrient content in breast milk. Breast milk contains whey protein and colostrum which are considered to be able to increase the immune system of vulnerable babies so that babies do not get sick easily such as diarrhea.[9].

\section{The relationship between maternal family support and the incidence of stunting}

Toddler care requires support from various parties, one of which is family support. The family's readiness to accept toddlers is an important thing to be used as an indicator. Ready families will provide various positive things including support. The support that can be felt is social support [10].

Family social support will have an impact on the growth and development of toddlers to the maximum, so that the family environment is a factor that encourages the formation of growth and development. Family support can also have an impact on meeting nutritional needs, especially during the period of growth and development[11].

The results showed that there was no statistical relationship with the incidence of stunting with a $\mathrm{p}$ value of 0.49 with an OR value of 0.49 . The family support needed includes emotional support and information so that a person will know that other people care, respect, love, and help him. Social support is also intended as the presence and willingness of meaningful people who can be trusted to help, encourage, accept, look after, and care for toddlers in meeting nutritional needs.[12].

\section{The relationship between maternal exposure to cigarette smoke and the incidence of stunting}

Various parties are needed in providing care to the people around us. Especially in the group of toddlers need special attention to grow and develop optimally. The attention needed includes the need for adequate environmental conditions[13].

A comfortable environment is free from air pollution caused by family members who smoke. The chemical compound content of cigarettes is estimated to be approximately 4000 types of compounds that can harm health. The main toxins in cigarettes are nicotine, tar and carbon monoxide. The content of cigarette smoke can have an impact on gene changes or mutations[14].

Cigarette smoke can cause clogged blood vessels. If there is blockage of blood vessels, the impact on the inhibition of substances that the body needs. Thus the vulnerability of the body can occur due to an imbalance and will lead to disease[15].

The same impact will be felt on toddlers who are exposed to cigarette smoke. Exposure to cigarette smoke causes people who are in the environment to become passive smokers. Passive smoking status increases the risk to health, especially toddlers.[16]

The results showed that there was no statistical relationship between exposure to cigarette smoke and the incidence of stunting with a $\mathrm{p}$ value of 0.09 . There is no statistical relationship and the OR value is less than 1; it can be caused by the lack of several respondents which causes a high level of homogeneity.

In addition to having a direct impact on the incidence of stunting, smoking is also an indirect cause of health problems. This 
happens because of family income which is spent more on buying cigarettes than on the nutritional needs of families, especially toddlers [17].

\section{The relationship between socioeconomic status and the incidence of stunting}

Economic factors are the main factors that affect nutritional status. Economic factors can also affect the level of education, family income, and food availability. Availability of food is the ability of families to meet the needs of sufficient food in terms of quantity and quality and safety. Lack of availability of food in a family continuously will cause disease due to malnutrition in the family[18].

Socio-economic status is a unique variable, in this case sometimes there is a reciprocal relationship between the two. In addition, economic factors will affect all sectors of life. Such as employment, education, access to health services and others[19].

\section{CONCLUSION}

There is a statistical relationship between exclusive breastfeeding and the incidence of stunting, while maternal height, family support, and exposure to cigarette smoke do not show a statistical relationship with the incidence of stunting in the stunting locus area, West Tapalang District.

\section{Acknowledgement: None}

\section{Conflict of Interest: None}

\section{Source of Funding: None}

\section{Ethical Approval: Approved}

\section{REFERENCES}

1. K. Berhe, O. Seid, Y. Gebremariam, A. Berhe, and N. Etsay, "Risk factors of stunting (chronic undernutrition) of children aged 6 to 24 months in Mekelle City, Tigray Region, North Ethiopia: An unmatched case-control study," PLoS One, vol. 14, no.
6, pp. 1-11, 2019, doi: 10.1371/journal.pone.0217736.

2. S. H. Barcellos, L. S. Carvalho, and P. Turley, "Education can reduce health differences related to genetic risk of obesity," Proc. Natl. Acad. Sci. U. S. A., vol. 115, no. 42, pp. E9765-E9772, 2018, doi: 10.1073/pnas.1802909115.

3. Nur Hadibah Hanum, "Hubungan Tinggi Badan Ibu dan Riwayat Pemberian MP-ASI dengan Kejadian Stunting pada Balita Usia 24-59 Bulan," Amerta Nutr., vol. 3, no. 2, pp. 2019, 28-84, doi: 10.2473/amnt.v3i2.2019.78-84.

4. N. Hidayah and M. Marwan, "Upaya Pemberdayaan Masyarakat Dalam Menciptakan Generasi Milenial Sadar Gizi Yang Bebas Stunting Melalui Kegiatan 1000 HPK," J. Community Engagem. Heal., vol. 3, no. 1, pp. 86-93, 2020, doi: 10.30994/jceh.v3i1.41.

5. E. A. Kragel, A. Merz, D. M. N. Flood, and K. E. Haven, "Risk factors for stunting in children under the age of 5 in rural guatemalan highlands," Ann. Glob. Heal., vol. 86, no. 1, pp. 1-5, 2020, doi: 10.5334/aogh.2433.

6. N. Rohmawati and R. B. Antika, "Risk factors stunting incidence in children aged 6-36 months in jember regency," 3rd Int. Nurs. Conf., pp. 128-136, 2017, [Online]. Available:

https://jurnal.unej.ac.id/index.php/prosiding/ issue/view/622.

7. B. A. Paramashanti, H. Hadi, and I. M. A. Gunawan, "Pemberian ASI eksklusif tidak berhubungan dengan stunting pada anak usia 6-23 bulan di Indonesia," J. Gizi dan Diet. Indones. (Indonesian J. Nutr. Diet., vol. 3, no. 3, p. 162, 2016, doi: 10.21927/ijnd.2015.3(3).162-174.

8. Z. Zhu et al., "Association of infant and young child feeding practices with cognitive development at 10-12 years: A birth cohort in rural Western China," Br. J. Nutr., vol. 123, no. 7, pp. 768-779, 2020, doi: 10.1017/S0007114519003271.

9. S. Handayani, W. N. Kapota, and E. Oktavianto, "Hubungan Status Asi Eksklusif Dengan Kejadian Stunting Pada Batita Usia 24-36 Bulan Di Desa Watugajah Kabupaten Gunungkidul," Med. Respati J. Ilm. Kesehat., vol. 14, no. 4, p. 287, 2019, doi: 10.35842/mr.v14i4.226. 
10. H. W. Wulandari and I. Kusumastuti, "Pengaruh Peran Bidan, Peran Kader, Dukungan Keluarga dan Motivasi Ibu terhadap Perilaku Ibu dalam Pencegahan Stunting pada Balitanya," J. Ilm. Kesehat., vol. 19, no. 02, pp. 73-80, 2020, doi: 10.33221/jikes.v19i02.548.

11. I. Budiastutik and A. Nugraheni, "Determinants of Stunting in Indonesia: A Review Article," Int. J. Heal. Res., vol. 1, no. 1, pp. 2620-5580, 2018.

12. N. Salamung, J. Haryanto, and F. Sustini, "Faktor-Faktor yang Berhubungan dengan Perilaku Pencegahan Stunting pada Saat Ibu Hamil di Wilayah Kerja Puskesmas Kabupaten Bondowoso," J. Penelit. Kesehat. Suara Forikes, vol. 10, no. 5, pp. 264-269, 2019.

13. B. Rahayu and S. Darmawan, "Hubungan Karakteristik Balita, Orang Tua, Higiene dan Sanitasi Lingkungan terhadap Stunting pada Balita," Binawan Student J., vol. 1, no. 1, pp. 22-26, 2019, [Online]. Available: http://journal.binawan.ac.id/index.php/bsj/ar ticle/view/46/47.

14. S. A. Widyawati, S. Wahyuni, and A. Afandi, "Factors Related to Stunting Events in Children," vol. 25, no. 6, pp. 3324-3332, 2021, [Online]. Available: https://www.annalsofrscb.ro/index.php/jour $\mathrm{nal} /$ article/view/6059.

15. H. A. Hidayat and G. Gumilang, "Sistem Pakar Diagnosis Penyakit Yang Disebabkan Oleh Rokok Dengan Metode Forward
Chaining," Jutekin, vol. 5, no. 2, p. 5, 2017, [Online]. Available: http://jurnal.stmikdci.ac.id/index.php/jutekin/article/download /179/140.

16. H. Prasetya1 and Tri Siswati2, "Deklarasi sebar canting (sehat bebas asap rokok untuk cegah stunting) di Kalurahan Argodadi, Kapanewon Sedayu, Kab Bantul.," no. 18, pp. 1531-1537, 2021.

17. A. Marianti, "Analisis Pengaruh Faktor Sosial Ekonomi, Pendapatan dan Harga Rokok Terhadap Konsumsi Rokok di Indonesia Analysis of the Effects of SocioEconomic Factors, Cigarette Revenue and Prices on Cigarette Consumption in Indonesia," vol. 01, no. 1, pp. 34-48, 2020.

18. D. Fedriansyah, B. A. Paramashanti, and Y. Paratmanitya, "Faktor Sosial Ekonomi Dan Stunting Pada Anak Usia 6-23 Bulan," Media Gizi Pangan, vol. 27, no. September, p. 2020, 2020, doi: 10.32382/mgp.v27i1.1568.

19. S. Mary, "How much does economic growth contribute to child stunting reductions?," Economies, vol. 6, no. 4, 2018, doi: 10.3390/economies6040055.

How to cite this article: Rahmat Haji Saeni, Erdiawati Arief. Family biopsychosocial characteristics on stunting events in children in stunting locus areas Tapalang Barat district. Int J Health Sci Res. 2022; 12(1): 124-129. DOI: https://doi.org/10.52403/ijhsr.20220118 